\title{
PELAKSANAAN UNIT PRODUKSI PADA SEKOLAH MENENGAH KEJURUAN NEGERI KELOMPOK BISNIS DAN MANAJEMEN
}

\author{
Rusnani \\ SMKN 1 Banjarmasin Kalimantan Selatan \\ arusnani@yahoo.com.
}

\begin{abstract}
Abstrak: Pelaksanaan Unit Produksi/Jasa pada Sekolah Menengah Kejuruan Negeri Kelompok Bisnis dan Manajemen. Penelitian ini bertujuan untuk mengetahui (1) tingkat keefektifan pengelolaan administrasi pada unit produksi/jasa (UP/J), (2) keefektifan pelaksanaan pembelajaran pada UP/J, (3) pencapaian tujuan pada UP/J, (4) tindak lanjut pendampingan pada unit produksi/jasa SMKN kelompok bisnis dan manajemen di Banjarmasin, dan (5) faktor pendukung/ penghambat Pelaksanaan Unit Produksi sebagai sarana pembelajaran. Penelitian ini merupakan penelitian deskriptif. Pelaksanaan penelitian di SMKN 1 dan SMKN 3 kelompok bisnis dan manajemen di Banjarmasin pada bulan Nopember 2011 sampai dengan bulan Mei 2012. Subjek penelitian adalah guru, siswa dan karyawan yang terlibat dalam pengelolaan dan pelaksanaan Unit Produksi sebanyak 90 responden. Pengumpulan data menggunakan angket dan wawancara. Analisis data dilakukan dengan teknik deskriptif kuantitatif. Hasil penelitian adalah sebagai berikut (1) Pengelolaan administrasi meliputi perencanaan, pelaksanaan, pelaporan dan pengendalian dengan rerata sebesar 3,33 yang tergolong pada kategari efektif. (2) Pelaksanaan pembelajaran UP/J meliputi persiapan pembelajaran, pelaksanaan pembelajaran, kualifikasi guru pembimbing dan ketersediaan sarana dan prasarana dengan rerata sebesar 3,18 yang tergolong pada kategari efektif. (3) Pencapaian tujuan menunjukkan rerata sebesar 3,09 yang tergolong pada kategari efektif. (4) Tindak lanjut program unit produksi/jasa meliputi pencatatan administrasi pendampingan siswa, motivasi dan monitoring dan evaluasi keberhasilan siswa dengan rerata sebesar 3,07 yang tergolong pada kategari efektif. (5) faktor-faktor pendukung pelaksanaan UP/J sebagai sarana pembelajaran yaitu pengelola yang cukup baik, fasilitas memadai, ketersediaan dana, partisipasi langsung dari warga sekolah, dan adanya kerjasama yang baik antara sekolah dengan dunia usaha/industri, sedangkan faktor penghambat pelaksanaan UP/J sebagai sarana pembelajaran yaitu persepsi orang tua yang tidak mendukung anaknya dalam pemasaran produk, keterbatasan waktu yang dimiliki oleh guru dalam pendampingan kegiatan program UP/J di sekolah, kurangnya koordinasi antara guru dengan karyawan, kurangnya komunikasi sesama guru, harga barang dagangan dari produsen yang cukup tinggi, dan kurangnya motivasi siswa dalam mengikuti kegiatan program UP/J di sekolah.
\end{abstract}

Kata Kunci: pelaksanaan, program unit produksi/jasa, sarana pembelajaran 


\title{
THE IMPLEMENTATION OF THE PRODUCTION/SERVICE UNIT IN PUBLIC VOCATIONAL HIGH SCHOOLS OF THE BUSINESS AND MANAGEMENT CLUSTER
}

\begin{abstract}
The Implementation of the Production/Service Unit in Public Vocational High Schools of the Business and Management Cluster. This study aimed to investigate (1) the effectiveness of the administrative management in the PSU, (2) the effectiveness of the learning implementation in the PSU, (3) the attainment of objectives (outputs) in the PSU, (4) the follow-up of the guidance in the PSU in public vocational high schools (VHS/SMKN) of the Business and Management Cluster in Banjarmasin, and (5) the facilitating/ inhibiting factors in the implementation of the PSU as a learning facility. This was a descriptive study. It was conducted in SMKN 1 and SMKN 3 of the Business and Management Cluster in Banjarmasin from November 2011 to May 2012. The research subjects, consisting of 90 respondents, comprised teachers, students, and administrative personnel involved in the management and implementation of the Production Unit. The data were collected through a questionnaire and interviews, and analyzed using the quantitative descriptive technique. The results of the study are as follows. (1) The administrative management consists of planning, actuating, reporting, and controlling, with a mean of 3.33, which is in the effective category. (2) The learning implementation of the PSU consists of learning preparation, learning implementation, qualifications of supervising teachers, and the availability of infrastructure facilities with a mean of 3.18, which is in the effective category. (3) The attainment of objectives (outputs) gets a mean of 3.09, which is in the effective category. (4) The follow-up of the program of the PSU consists of the recording of student guidance administration, motivation, and monitoring and evaluation of students' success with a mean of 3.07, which is in the effective category. (5) The facilitating factors in the implementation of the PSU as a learning facility include relatively good management, adequate facilities, direct participation of school members, and cooperation between schools and business/industrial sectors; meanwhile, the inhibiting factors in the implementation of the PSU as a learning facility include parents' perception that does not support their children in the product marketing, the limited time that teachers have to guide the activities of the PSU program at school, lack of coordination between teachers and administrative personnel, lack of communication among teachers, high prices of merchandise from producers, and lack of students' motivation to join the activities of the PSU program at school.
\end{abstract}

Keywords: implementation, production/service unit program, learning facility 


\section{PENDAHULUAN}

Krisis ekonomi dalam jangka panjang membawa dampak yang sangat berarti bagi dunia perdagangan dan pemasaran. Dengan demikian dibutuhkan jiwa dan keterampilan kewirausahaan masyarakat untuk menggerakkan roda perekonomian, industri, perdagangan dan jasa dengan harapan dapat menopang kebutuhan hidup sehari-hari termasuk biaya pendidikan anak... Penanaman jiwa dan keterampilan wirausaha dapat dilaksanakan melalui pendidikan formal di sekolah, maupun nonformal di masyarakat.. Pendidikan kejuruan di SMK memberikan bekal kepada peserta didik untuk bekerja guna menopang kehidupannya (Finch \& Crunkilton, 1993:71)

Kompetensi kewirausahaan tersebut dapat diperoleh melalui pembelajaran di UP/J Sekolah. Namun kenyataan di lapangan, banyak unit produksi/jasa SMK yang dikelola dengan sederhana belum menerapkan prinsip-prinsip manajemen sehingga gagal. Selain itu data menunjukkan bahwa $72 \%$ unit produksi/jasa tidak dikelola oleh manajer yang profesional (Dit P2TK.PMPTK,2002) karena pelayanan kepada konsumen yang tidak memuaskan, sikap mental tenaga penjual yang lemah, dan tanggung jawab usaha yang rendah. Untuk pengembangan unit produksi/jasa membutuhkan dukungan sumber daya manusia secara profesional sangatlah dibutuhkan. Unit Produksi/Jasa Sekolah mempunyai harapan kedepan agar menghasilkan manfaat secara edukatif, ekonomi bagi warga sekolah, sosial atau masyarakat sekitar.

\section{Pengertian Unit Produksi Sekolah}

Secara umum unit produksi/jasa merupakan suatu proses kegiatan usaha yang dilakukan di dalam sekolah dan bersifat bisnis serta dilakukan oleh warga sekolah (Kepala sekolah, ketua jurusan/ program, guru, dan siswa) dengan memberdayakan sumber daya sekolah yang dimiliki serta dikelola secara profesional. Dengan kata lain unit produksi merupakan suatu aktivitas bisnis yang dilakukan secara berkesinambungan dalam mengelola sumber daya sekolah sehingga dapat menghasilkan produk dan jasa yang mendatangkan keuntungan. Pengertian tersebut pada dasarnya berakar pada pengertian budaya industri dalam upaya meningkatkan produktivitas kerja melalui perwujudan etos kerja. Secara organisasi, budaya perusahaan atau industri sebagai suatu nilai yang menjadi pegangan bagi setiap pekerja baik sebagai atasan maupun bawahan dalam menjalankan kewajibannya dan juga perilakunya.

Di samping memperoleh pembinaan keterampilan kejuruan selama melaksanakan aktivitas di unit produksi, siswa memperoleh pembinaan di bidang pengelolaan unit usaha yang bersifat bisnis. Pembinaan siswa secara langsung dalam bidang-bidang pekerjaan di unit produksi seperti menggunakan cash register, mendisplai produk, memberikan pelayanan kepada konsumen, mencatat persediaan barang dagangan, membuat laporan keuangan seperi neraca, rugi laba dan perubahan modal dan ikut menikmati hasil jerih payahnya dalam pengelolaan usaha tersebut (learning by doing). Seseorang tidak dapat menguasai teori dengan baik tanpa praktek, dan sebaliknya seseorang tidak dapat melakukan praktik secara efektif 
tanpa pemahaman teori. Sejalan dengan Finch \& Crunkilton (1999:11) yang menyatakan :

Learning and personal growth do not take place strictly within the confines of classroom or laboratory. Student develop skills and competence through a variety of learning activities and experiences that may not necessarily be counted as constructive credit for graduation.

Pernyataan tersebut dapat dimaknai, bahwa belajar dan pengembangan kepribadian tidak hanya terbatas di dalam kelas atau laboratorium. Siswa dapat mengembangkan keterampilan dan pengembangan kemampuannya melalui berbagai aktivitas pembelajaran dan pengalaman yang tidak memerlukan hitungan kredit seperti halnya lulusan lembaga pendidikan.

Dari beberapa uraian yang dikemukakan di muka dapat disimpulkan bahwa unit produksi adalah unit usaha yang memiliki keseimbangan antara aspek komersial dan aspek akademik, yang diselenggarakan dalam lingkup organisasi sekolah dengan memanfaatkan fasilitas yang dimiliki sekolah yang bersangkutan. Keuntungan itu dimanfaatkan untuk membantu pembiayaan pendidikan dan meningkatkan kesejahteraan bagi warga sekolah, termasuk siswa dan pengelola yang bersangkutan. Unit produksi pada umumnya bekerja dalam lingkup unit usaha sekolah, aktivitasnya tidak mengganggu program intrakurikuler.

Berdasarkan pedoman pelaksanaan unit produksi (Dikmenjur, 2007), tujuan penyelenggaraan kegiatan tersebut adalah: (1) wahana pelatihan berbasis produksi/jasa bagi siswa;(2) wahana menumbuhkan dan mengembangkan jiwa wirausaha guru dan siswa pada SMK/MAK;(3) sarana praktik produktif secara langsung bagi siswa;(4) membantu pendanaan untuk pemeliharaan, penambahan fasilitas dan biaya-biaya operasional pendidikan lainnya;(5) menambah semangat kebersamaan, karena dapat menjadi wahana peningkatan aktivitas produktif guru dan siswa serta memberikan 'income' serta peningkatan kesejahteraan warga sekolah; mengembangkan sikap mandiri dan percaya diri dalam pelaksanaan kegiatan praktik siswa.

\section{Prinsip-prinsip Unit Produksi}

Prinsip-prinsip yang harus diperhatikan pada pelaksanaan unit produksi sebagai berikut: (1) UP merupakan satu alternatif yang diharapkan dapat meningkatkan mutu lulusan SMK; (2) Penyelenggaraan UP dimaksudkan untuk mendapatkan keahlian profesional; (3)UP merupakan salah satu upaya dalam mengoptimalkan sumber daya yang dimiliki SMK;(4) UP dikelola secara profesional menganut prinsip manajemen bisnis;(5) UP harus menunjang dan tidak boleh menggangu kegiatan belajar mengajar; (6) Kegiatan unit produksi yang sudah layak dapat dijadikan sarana belajar dan bekerja (learning by doing) ;(7) Keuntungan UP dapat dimanfaatkan untuk melaksanakan kegiatan belajar mengajar di SMK dan peningkatan kesejahteraan warga SMK; (8) Pembagian keuntungan hasil kegiatan diatur sesuai keputusan manajemen secara profesional; (9) UP/J supaya digunakan sebagai salah satu ukuran keberhasilan sekolah dalam menjalankan fungsi menyiapkan tenaga kerja menengah. 


\section{Sikap Kerja Profesional dalam Pelaksanaan Unit Produksi/Jasa}

Kata profesional berasal dari kata profesi yang artinya suatu bidang pekerjaan yang ingin atau akan ditekuni oleh seseorang. Profesi juga diartikan sebagai suatu jabatan atau pekerjaan tertentu yang mensyaratkan pengetahuan dan keterampilan khusus yang diperoleh dari pendidikan akademis yang intensif. Menurut Kunandar (2007: 45) profesi adalah suatu pekerjaan atau jabatan yang menuntut keahlian tertentu tidak dapat dipegang oleh sembarang orang, tetapi memerlukan persiapan melalui pendidikan dan pelatihan secara khusus., sedangkan profesional diartikan memerlukan kepandaian khusus untuk menjalankan suatu profesi. Profesionalitas diartikan sebagai mutu, kualitas, dan tindak tanduk yang merupakan ciri suatu profesi atau orang yang profesional. Kaitan dengan profesional dikemukakan oleh Cooper (Wina Sanjaya, 2005:142) bahwa:

A Professional is a person who possesses some specialized knowledge and skills, can weigh alternatives, and can selec from among a number of potentially productive actions one that is particularly appropriate iin a given situation.

Dengan kata lain profesional adalah sebutan yang mengacu kepada sikap mental dalam bentuk komitmen dari para anggota suatu profesi untuk senantiasa mewujudkan dan meningkatkan sikap profesionalnya.

Profesionalitas dalam pekerjaan/ jabatan adalah suatu istilah terhadap kualitas sikap, pengetahuan dan keahlian individu suatu profesi dalam menjalankan tugas-tugas profesinya. Pernyataan ini sejalan dengan Uzer Usman (2007:14) yang menyatakan bahwa pekerjaan yang bersifat profesional memerlukan beberapa bidang ilmu yang secara sengaja harus dipelajari dan kemudian diaplikasikan bagi kepentingan umum.

Menurut Hadari Nawawi (2006:172), menjelaskan bahwa profesional dalam pekerjaan harus memenuhi tiga faktor sebagai berikut : (a) menguasai seperangkat keahlian yang dipersiapkan melalui program pendidikan atau pelatihan keahlian sebagai spesialisasi; (b) memiliki kemampuan untuk memperbaiki/ meningkatkan keterampilan dan/atau keahlian khusus yang dikuasai sesuai perkembangan dan kemajuan teknologi dibidangnya; (c) dihargai dengan penghasilan yang memadai sebagai imbalan profesi berdasarkan keahlian khusus yang dikuasai. Dari beberapa pernyataan di atas, maka dapat disimpulkan bahwa profesionalitas dalam pekerjaan/jabatan adalah seseorang atau sekelompok orang yang bekerja secara profesional dengan menggunakan keahlian serta kecakapan khusus dengan imbalan profesi berdasarkan keahlian atau kecakapan yang dimilikinya.

Menurut pedoman pelaksanaan kurikulum SMK penyelenggaraan Unit Produksi/Jasa di sekolah dimaksudkan untuk mendapatkan keahlian profesional bagi siswa yang hanya akan dapat diperoleh melalui mengerjakan pekerjaan langsung yang sesuai dengan kebutuhan pasar. Depdikbud (1993:41).

\section{Profil Unit Produksi SMK}

Menurut Direktorat Pembinaan Sekolah Menengah Kejuruan (2006:82), dalam penyelenggaraan SMK berstandar nasional maupun internasional disebutkan bahwa unit produksi SMK sejak awal diharapkan menjadi salah satu alternatif dan pendekatan melahirkan dunia usaha di lingkungan SMK, dengan 
memberdayakan seluruh aset dan potensi yang dimiliki SMK. Profil unit produksi SMK meliputi: (1) struktur organisasi: adanya struktur organisasi yang terintegrasi dengan struktur organisasi sekolah; (2) sumber permodalan: sistem permodalan melibatkan warga sekolah/stake holder termasuk siswa; (3) program: perencanaan kegiatan unit produksi dengan: (a) menerapkan konsep-konsep manajemen produksi, manajemen SDM, akuntansi keuangan, dan pemasaran, (b) kegiatan produksi terintegrasi dengan proses belajar mengajar, (c) kegiatan unit produksi menjadi alternatif pelaksanaan praktik kerja industri dan sebagai proses pelatihan kewirausahaan, (d) pemasaran produk melibatkan seluruh warga sekolah dan stake holder, termasuk alumni; (4) pengelolaan profit: profit terdistribusi dengan persentase yang disepakati bersama warga sekolah, mendukung dana operasional sekolah, pengembangan SDM, kegiatan sosial kemasyarakatan; (5) pembukuan dan pertanggungjawaban keuangan dilakukan mengikuti Standar Akuntansi Keuangan. Audit keuangan minimal satu kali dalam 3 bulan oleh tim audit yang dibentuk bersama warga sekolah, laporan pertanggungjawaban keuangan unit produksi dilakukan minimal setiap akhir tahun akademik.

\section{Keefektifan Pengelolaan Unit Produksi}

Ada beberapa pengertian mengenai keefektifan yang dikemukakan oleh para ahli, diantaranya Serian Wijatno (2009;279) yang menyatakan bahwa efektivitas merupakan indikator keberhasilan suatu organisasi dalam mencapai tujuannya, lebih lanjut dikatakan efektivitas tidak memperhatikan biaya yang dikeluarkan. Berapa pun biaya yang telah dikeluarkan suatu perusahaan jika mencapai tujuannya, maka dikatakan efektif. Menurut Peter Drucker (Handoko 2003:7), “ Efektivitas adalah melakukan pekerjaan yang benar (doing the right things). Lebih lanjut ditambahkannya, bahwa efektifitas merupakan kemampuan memilih sumber daya dengan alat dan teknologi yang tepat dalam mencapai tujuan yang telah ditetapkan. Sedangkan pendapat McDavid.J \& Hawthorn. L (2006) menyatakan bahwa "effectiveness are the observed outcome consistent with the intended objectives".

Artinya efektivitas adalah hasil yang dicapai sesuai dengan tujuan yang diinginkan. Pendapat diatas didukung oleh Gibson et al (2006:20),

what we mean by effectiveness.....is the accomplishment of recognized objectives of cooperative effort. The degree of accomplishment indicates the degree of effectiveness".

Keeefektifan UP/J SMK adalah keberhasilan pengelolaan yang dijalankan suatu UP/J yang berada di lingkungan sekolah sehingga tercapai tujuan yang telah ditetapkan.

\section{Kinerja Kepala Sekolah}

Kepala Sekolah adalah pimpinan tertinggi di sekolah. Pola kepemimpinannya akan sangat berpengaruh bahkan sangat menentukan terhadap kemajuan sekolah, sehingga harus memiliki kemampuan administrasi, memiliki komitmen tinggi, dan luwes dalam melaksanakan tugasnya. Kepala sekolah juga harus melakukan peningkatan profesionalisme sesuai gaya kepemimpinannya, berangkat dari kemauan dan kesediaan, bersifat memprakarsai dan didasari pertimbangan yang matang, lebih berorientasi kepada bawahan, demograsi, lebih 
berfokus pada hubungan dari pada tugas, serta mempertimbangkan kematangan bawahan.

Kepala sekolah memiliki potensi yang dapat dikembangkan secara optimal. Setiap kepala sekolah harus memiliki perhatian yang cukup tinggi terhadap peningkatan kualitas pendidikan di sekolah. Perhatian tersebut harus ditunjukkan dalam kemauan dan kemampuan untuk mengembangkan diri dan sekolahnya secara optimal. Kepala sekolah memiliki peran yang kuat dalam mengkoordinasikan, menggerakkan dan menyerasikan semua sumber daya pendidikan yang tersedia disekolah.

Kepemimpinan kepala sekolah merupakan salah satu faktor yang dapat mendorong sekolah untuk dapat mewujudkan visi, misi, tujuan dan sasaran sekolahnya melalui program-program yang dilaksanakan secara terencana dan bertahap. Oleh karena itu kepala sekolah dituntut mempunyai kemampuan manajemen dan kepemimpinan yang memadai agar mampu mengambil inisiatif dan prakarsa untuk meningkatkan mutu sekolah. Fidler.B ( 2002:32) menyatakan

"Leadership involves such roles as: Entrepreneur: identifying new opportunities, motivator: inspiring and motivating others to commit",

makna dari pernyataan diatas seorang kepala sekolah harus mampu berperan sebagai wirausaha, mampu mengidentifikasi peluang baru, menginspirasi dan memotivasi orang lain untuk melakukan sesuatu. Kepemimpinan kepala sekolah berperan dalam menentukan manajer yang akan mengelola UP/J di sekolah. Hal ini perlu dipertimbangkan kepala sekolah dan manajer UP/J demi tercapainya tujuan dan efektivitas pengelolaan UP/J sekolah. Rappe \& Zwick (2007) menyatakan
Imply that it is advisable to improve frontline managers' leadership compentencies and identity, and that leadership development can contribute to closing the competence gaps.

Manajer unit produksi/Jasa sebaiknya meningkatkan kompetensi pribadi dan kepemimpinan yang dimilikinya. Pengembangan sikap kepemimpinan memberikan kontribusi dalam menutupi kurangnya kompetensi yang dimiliki pengelola.

Dinas pendidikan telah menetapkan bahwa kepala sekolah harus mampu melaksanakan pekerjaannya sebagai educator, manager, administrator, dan supervisor. Dalam perkembangan selanjutnya sesuai dengan kebutuhan masyarakat dan perkembangan zaman, kepala sekolah juga harus mampu berperan sebagai leader, innovator, dan motivator di sekolahnya. Mulyasa (2005:98). Dengan demikian dapat disimpulkan bahwa peran kepala sekolah merupakan akumulasi sikap, pengetahuan dan kemampuan seseorang kepala sekolah dalam meningkatkan kualitas pendidikan di sekolahnya secara optimal dengan memberdayakan segenap sumber daya yang dimiliki sekolah.

\section{METODE}

Penelitian ini merupakan penelitian deskriptif, yang bertujuan untuk memperoleh informasi dalam pelaksanaan program UP/J yang dilaksanakan pada SMKN Kelompok bisnis dan manajemen di Banjarmasin.

Penelitian ini dilaksanakan pada SMKN 1 dan SMKN 3 kelompok bisnis dan manajemen di Banjarmasin. Waktu penelitian dimulai pada bulan November 2011 sampai dengan bulan Maret 2012. 
Subyek penelitian dalam evaluasi pelaksanaan UP/J adalah guru kewirausahaan, guru produktif, siswa dan karyawan yang terlibat dalam kegiatan UP yang berjumlah 90 orang.

Variabel dalam penelitian ini adalah variabel tunggal yakni efektivitas pelaksanaan UP/J di SMKN Kelompok Binis dan manajemen di Banjarmasin. Aspek yang akan dinilai meliputi:

1. Pengelolaan Administrasi Program UP/J.

2. Pelaksanaan Pembelajaran/praktik pada $\mathrm{UP} / \mathrm{J}$.

3. Pencapaian Tujuan pada UP/J.

4. Tindak Lanjut Pendampingan usaha pada $\mathrm{UP} / \mathrm{J}$.

5. Faktor pendukung dan penghambat dalam pelaksanaan kegiatan UP/J
Metode yang digunakan untuk memperoleh data sebagaimana yang diinginkan dalam penelitian ini, yaitu dengan metode angket dan wawancara angket.

\section{HASIL PENELITIAN}

\section{Pengelolaan Administrasi Program Unit Produksi/Jasa}

Pengelolaan administrasi Program UP/J terdiri dari 22 item pertanyaan dengan 3 indikator yaitu perencanaan, pelaksanaan, pelaporan, dan pengendalian. Berdasarkan hasil deskripsi dengan bantuan software statistik diperoleh rerata (mean) sebesar 3,33; median 3,37; modus 3,86; standar deviasi 0,39. Rerata skor tersebut berada pada interval 3,33 s.d 3,72 kategari efektif.

Tabel 1. Pengelolaan Administrasi Program Unit Produksi/Jasa

\begin{tabular}{ccccl}
\hline \hline No & Rentang Skor & $\begin{array}{c}\text { Frekuensi } \\
(\mathbf{F})\end{array}$ & $\begin{array}{c}\text { Persentase } \\
(\boldsymbol{\%})\end{array}$ & \multicolumn{1}{c}{ Kategorisasi } \\
\hline 1 & $\mathrm{X} \geq 3,72$ & 16 & 17,8 & Sangat Efektif \\
2 & $3,33 \leq \mathrm{X}<3,72$ & 31 & 34,4 & Efektif \\
3 & $2,95 \leq \mathrm{X}<3,33$ & 27 & 30,0 & Kurang Efektif \\
4 & $\mathrm{X}<2,95$ & 16 & 17,8 & Tidak Efektif \\
\hline & Total & $\mathbf{9 0}$ & $\mathbf{1 0 0 . 0}$ & \\
\hline
\end{tabular}

Berdasarkan Tabel 3 sebagian besar responden menilai bahwa pengelolaan administarsi Program Unit produksi/Jasa termasuk efektif. Hal ini menunjukkan bahwa pengelolaan administarsi Program Unit produksi/Jasa di SMKN Kelompok Bisnis dan
Manajemen di Banjarmasin sudah termasuk efektif.

Hasil perbandingan distribusi frekuensi pengelolaan administarsi Program UP/J dapat dilihat melalui grafik batang berikut ini. 


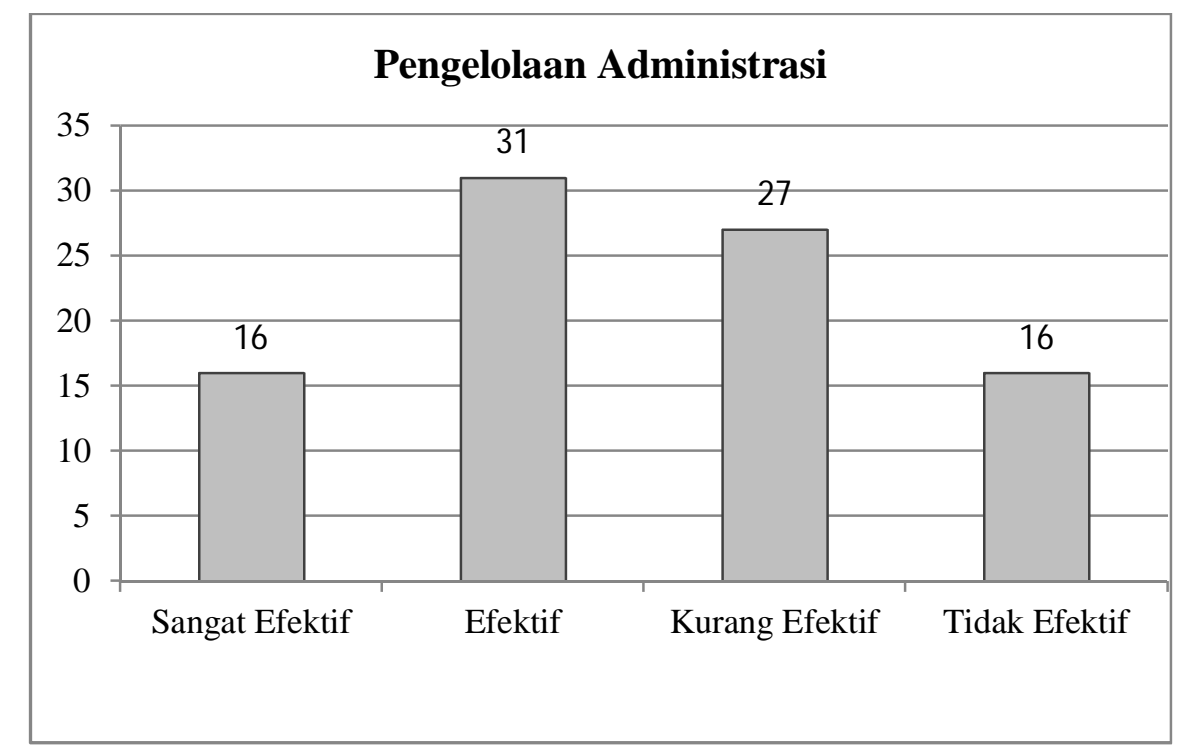

Gambar 1. Perbandingan Tingkat Keefektifan Pengelolaan Administrasi Program Unit Produksi/Jasa

\section{Pelaksanaan Pembelajaran Program Unit Produksi/Jasa}

Pelaksaaan pembelajaran program UP/J terdiri dari 38 item pertanyaan yang didalamnya terdapat 4 indikator yaitu persiapan pembelajaran, inti pelaksanaan pembelajaran, kualifikasi guru pembimbing dan ketersediaan sarana dan prasarana. Hasil statistik deskripsi dengan bantuan software statistik diperoleh mean sebesar 3,18; median 3,22; modus 3,01; standar deviasi 0,38 . Rerata skor tersebut berada pada interval 3,18 s.d 3,56 kategori efektif. Tabel 4 menunjukkan bahwa pelaksanaan pembelajaran Program UP/J dalam kategori efektif yaitu 33 responden (36,6\%) Hasil tersebut menunjukkan bahwa keefektifan pelaksanaan pembelajaran Program UP/J di SMKN Kelompok Bisnis dan Manajemen di Banjarmasin sudah berjalan efektif.

Tabel 2. Pelaksanaan Pembelajaran Program Unit Produksi/Jasa

\begin{tabular}{ccccl}
\hline \hline No & Rentang Skor & $\begin{array}{c}\text { Frekuensi } \\
(\mathbf{F})\end{array}$ & $\begin{array}{c}\text { Persentase } \\
(\boldsymbol{\%})\end{array}$ & \multicolumn{1}{c}{ Kategorisasi } \\
\hline \hline 1 & $\mathrm{X} \geq 3,56$ & 14 & 15,6 & Sangat Efektif \\
2 & $3,18 \leq \mathrm{X}<3,56$ & 33 & 36,6 & Efektif \\
3 & $2,81 \leq \mathrm{X}<3,18$ & 27 & 30,0 & Kurang Efektif \\
4 & $\mathrm{X}<2,81$ & 16 & 17,8 & Tidak Efektif \\
\hline & Total & $\mathbf{9 0}$ & $\mathbf{1 0 0 . 0}$ & \\
\hline
\end{tabular}

Hasil perbandingan distribusi frekuensi pelaksanaan pembelajaran Program UP/J di SMKN Kelompok Bisnis dan Manajemen di
Banjarmasin juga dapat dilihat melalui grafik batang berikut ini. 


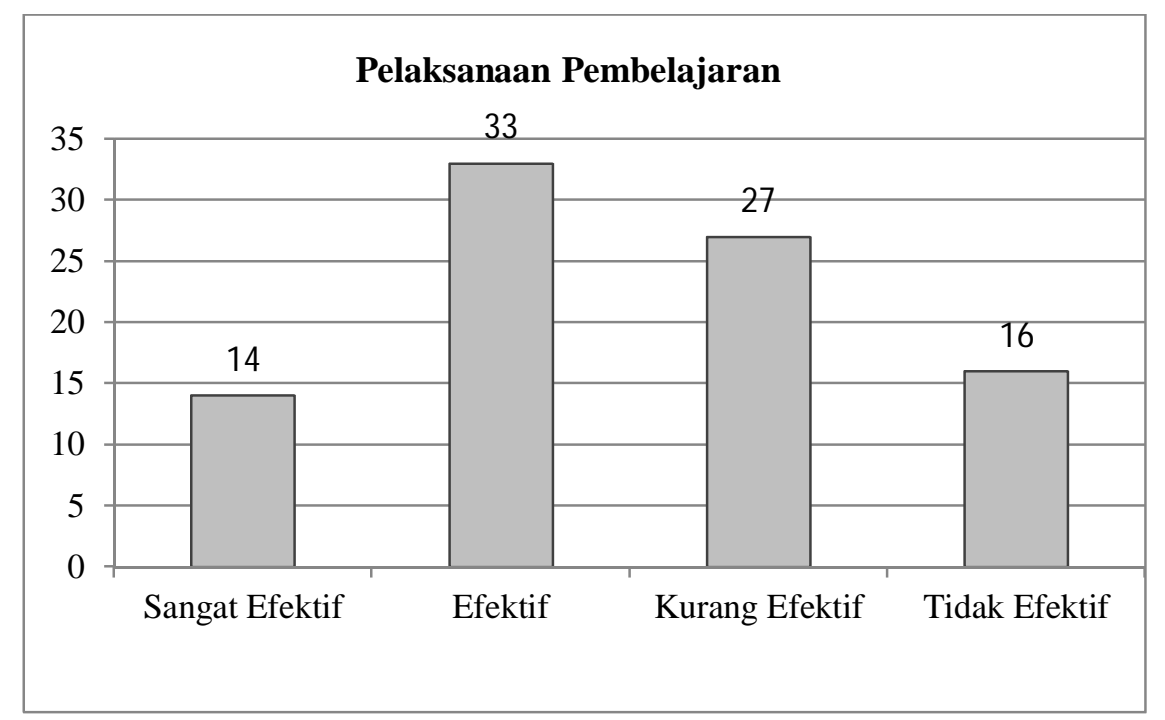

Gambar 2. Perbandingan Tingkat Keefektifan Pelaksanaan Pembelajaran Program Unit Produksi/Jasa

\section{Pencapaian Tujuan Program Unit median 3,14; modus 3,14; standar deviasi 0,55. Produksi/Jasa \\ Rerata skor tersebut berada pada interval 3,09 \\ Hasil statistik deskripsi dengan bantuan s.d 3,64 kategari efektif.} software statistik diperoleh mean sebesar 3,09;

Tabel 3. Pencapaian Tujuan Program Unit Produksi/Jasa

\begin{tabular}{|c|c|c|c|l|}
\hline \hline No & Rentang Skor & $\begin{array}{c}\text { Frekuensi } \\
(\mathbf{F})\end{array}$ & $\begin{array}{c}\text { Persentase } \\
(\mathbf{\%})\end{array}$ & Kategorisasi \\
\hline \hline 1 & $\mathrm{X} \geq 3,64$ & 19 & 21,1 & Sangat Efektif \\
\hline 2 & $3,09 \leq \mathrm{X}<3,64$ & 32 & 35,6 & Efektif \\
\hline 3 & $2,53 \leq \mathrm{X}<3,09$ & 29 & 32,2 & Kurang Efektif \\
\hline 4 & $\mathrm{X}<2,53$ & 10 & 11,1 & Tidak Efektif \\
\hline \multicolumn{2}{|c|}{ Total } & $\mathbf{9 0}$ & $\mathbf{1 0 0 . 0}$ & \\
\hline
\end{tabular}

Berdasarkan Tabel 5 di atas, sebagian besar responden menunjukkan bahwa pencapain tujuan Program UP/J termasuk dalam kategori efektif yaitu 32 responden $(35,6 \%)$.
Hasil perbandingan distribusi frekuensi pencapain tujuan Program UP/J di SMKN Kelompok Bisnis dan Manajemen di Kota Banjarmasin juga dapat dilihat melalui grafik batang berikut ini. 


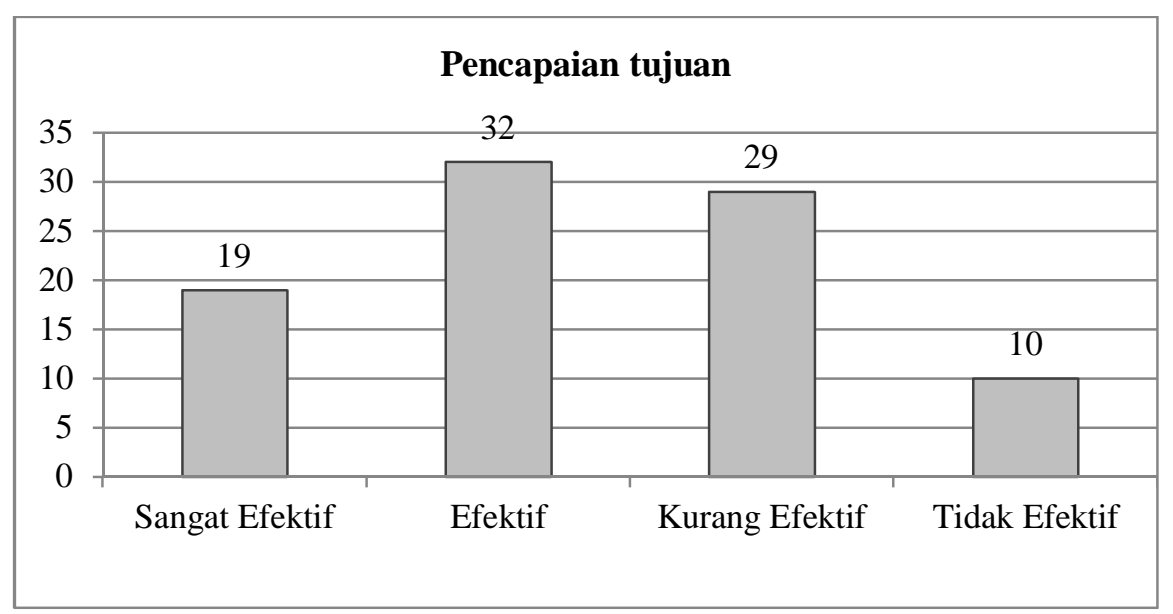

Gambar 3. Perbandingan Tingkat Keefektifan Pencapaian Tujuan Program Unit Produksi/Jasa

Tindak Lanjut Program Unit Produksi/Jasa

Hasil statistik deskripsi dengan bantuan software statistik diperoleh mean sebesar 3,07; median 3,08; modus 3,35; standar deviasi 0,37.

Rerata skor tersebut berada pada interval 3,07 s.d 3,44 kategari efektif.

Tabel 4. Tindak Lanjut Program Unit Produksi/Jasa

\begin{tabular}{ccccl}
\hline \hline No & Rentang Skor & $\begin{array}{c}\text { Frekuensi } \\
(\mathbf{F})\end{array}$ & $\begin{array}{c}\text { Persentase } \\
(\mathbf{\%})\end{array}$ & \multicolumn{1}{c}{ Kategorisasi } \\
\hline \hline 1 & $\mathrm{X} \geq 3,44$ & 12 & 13,3 & Sangat Efektif \\
2 & $3,07 \leq \mathrm{X}<3,44$ & 35 & 38,9 & Efektif \\
3 & $2,71 \leq \mathrm{X}<3,07$ & 31 & 34,5 & Kurang Efektif \\
4 & $\mathrm{X}<2,71$ & 12 & 13,3 & Tidak Efektif \\
\hline & Total & $\mathbf{9 0}$ & $\mathbf{1 0 0 . 0}$ & \\
\hline
\end{tabular}

Berdasarkan tabel 6 terlihat bahwa keefektifan tindak lanjut Program UP/J sudah termasuk efektif yaitu 35 responden $(38,9 \%)$.
Untuk lebih jelasnya mengenai perbandingan tingkat keefektifan tindak lanjut Program UP/J dapat dilihat dari gambar grafik berikut ini.

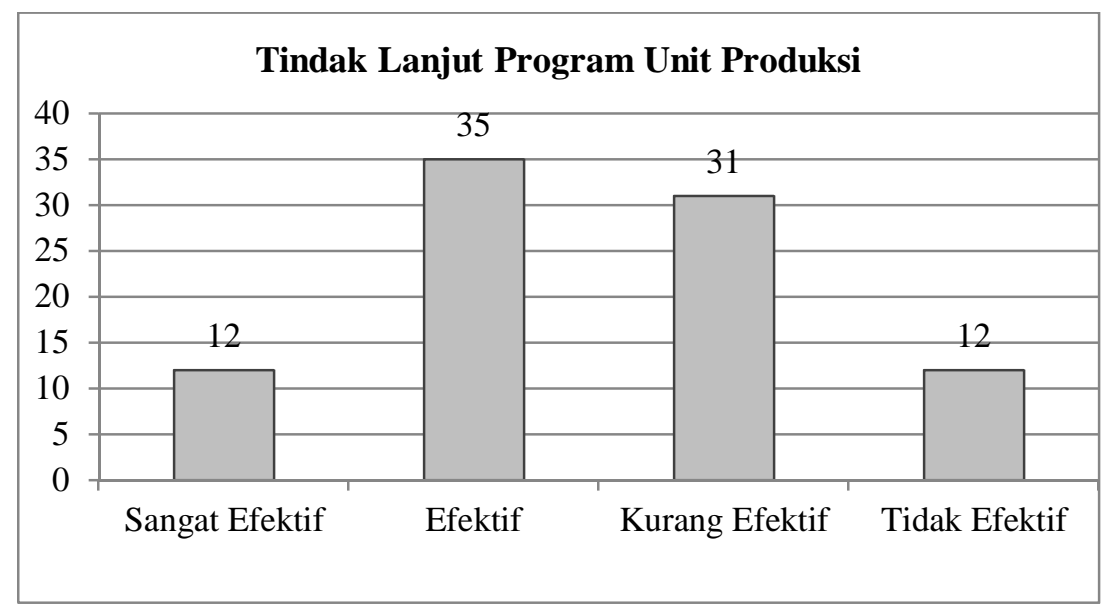

Gambar 4. Perbandingan Tingkat Keefektifan Tindak Lanjut Pendampingan Program Unit Produksi/Jasa 
Faktor pendukung/penghambat pelaksanaan unit produksi di SMKN Kelompok bisnis dan manajemen di Banjarmasin

Data mengenai faktor pendukung dan penghambat dalam pelaksanaan unit produksi sebagai teaching factory, disajikan pada tabel 7 di bawah ini.

Tabel 5. Faktor Pendukung dan Penghambat dalam Pelaksanaan UP/J sebagai Teaching Factory

\begin{tabular}{|c|c|c|c|}
\hline No & Nama Sekolah & Faktor Pendukung & Faktor Penghambat \\
\hline 1 & SMKN 1 & $\begin{array}{l}\text { 1. Dana hibah dari Direktorat } \\
\text { 2. Lokasi bisnis center yang } \\
\text { strategis } \\
\text { 3. Koordinator yang memiliki jiwa } \\
\text { bisnis } \\
\text { 4. Pangsa Pasar yang jelas dan } \\
\text { dengan jumlah siswa,guru serta } \\
\text { karyawan cukup besar sekitar } \\
1400 \text { orang } \\
\text { 5. Sarana dan prasarana yang } \\
\text { dimiliki } \\
\text { 6. Kepemimpinan }\end{array}$ & $\begin{array}{l}\text { 1. Tanggapan dari orang } \\
\text { tua yang keberatan } \\
\text { anaknya disuruh } \\
\text { berjualan } \\
\text { 2. Harga dari distributor } \\
\text { terlalu tinggi } \\
\text { 3. Kesibukan guru dan } \\
\text { pengurus } \\
\text { 4. Kurang koordinasi } \\
\text { antara pengurus/ } \\
\text { karyawan dengan guru } \\
\text { pembimbing }\end{array}$ \\
\hline 2 & SMKN 3 & $\begin{array}{l}\text { 1. Sumber Daya Manusia } \\
\text { 2. Fasilitas yang dimiliki sekolah } \\
\text { 3. Produk yang dijual adalah } \\
\text { kebutuhan sehari-hari } \\
\text { 4. Pangsa pasar yang jelas } \\
\text { 5. Hubungan kerjasama dengan } \\
\text { Stakeholder }\end{array}$ & $\begin{array}{l}\text { 1. Kendala pemasaran } \\
\text { 2. Kesibukan Guru dan } \\
\text { siswa } \\
\text { 3. Motivasi guru } \\
\text { 4. Komunikasi sesama } \\
\text { guru di sekolah }\end{array}$ \\
\hline
\end{tabular}

PEMBAHASAN

\section{Pelaksanaan UP/J sebagai sarana pembelajaran}

\section{Pengeloaan Administrasi Program Unit Produksi/Jasa}

Hasil penelitian mengenai pengelolaan administrasi Program UP/J menunjukkan bahwa sebagian besar responden menilai pengelolaan administrasi Program UP/J di SMKN Kelompok bisnis dan manajemen di Banjarmasin sebagian besar menilai efektif yaitu 31 responden $(34,4 \%)$.
Pada dasarnya setiap sekolah mempunyai masing-masing satu unit produksi yang dikelola oleh satu koordinator unit produksi. Kriteria organisasi dan mekanisme pengelolaan UP/J dinyatakan berhasil apabila telah menyusun dan melaksanakan administrasi secara optimal yang kemudian dievaluasi secara berkala untuk melihat efektivitas kerja pengelola, membuat jadwal dan tata tertib kegiatan UP/J, rencana kerja bulanan/tahunan, struktur organisasi, fungsi, tugas, dan wewenang. Struktur organisasi UP/J SMK berisi 
sistem penyelenggaraan dan administrasi yang diuraikan secara jelas dan transparan.

Pada pengelolaan administrasi didalamnya terdapat perencanaan, pelaksanaan, pelaporan dan pengendalian. Pelaksanaan merupakan penyusunan pengorganisasian dalam Program UP/J. Beberapa hal yang harus diperhatikan dalam membuat strukur organisasi UP/J SMK (Dikmenjur, 2007) antara lain, 1) organisasi dan manajemen UP disusun secara flat, 2) lebih menekankan pada kerja tim, anggota tim, karyawan dilibatkan dan diberdayakan, 3) adanya pendelegasian tugas dan wewenang yang jelas kepada setiap unit kerja dan pelaksana, 4) mengembangkan prinsip 'desentralisasi' dan otoritas dalam pembagian tugas dan wewenang, 5) kejelasan peran dan tanggungjawab personel dan pengelola, 5) gaya kepemimpinan sekolah bersifat luwes, fleksibel dan demokratis, dan 6) Staffing. pelaporan, berkaitan dengan laporan keuangan dan laporan evaluasi pelaksanaan program baik jangka pendek, menengah, maupun jangka panjang. Sedangkan pengendalian dilakukan untuk melakukan pengaturan atau pengarahan dalam organisasi agar tujuan tercapai. Pengendalian fisik, misal: (a) bahan baku, (b) kualitas produk, (c) peralatan produksi, dan (d) kapasitas mesin, dll. Pengendalian Personel, meliputi: (a) penempatan pekerja baru, (b) diklat karyawan, dan (c) penggajian dan prestasi kerja. Pengendalian Informasi, meliputi: (a) informasi pemasaran dan penjualan, (b) informasi analisis lingkungan, (c) jadwal produksi, dan (d) pengendalian financial. Apabila ke-4 indikator ini berhasil dilaksanakan dengan maksimal, maka keberhasilan suatu pengelolaan administrasi Program UP/J akan diperoleh.

\section{Pelaksanaan Pembelajaran Program Unit Produksi/Jasa}

Pelaksanaan pembelajaran Program UP/J di SMKN Kelompok bisnis dan manajemen di Banjarmasin menunjukkan bahwa sebagian besar pelaksanaan pembelajaran ProgramUP/J termasuk efektif yaitu 33 responden $(36,6 \%)$.

Pelaksanaan pembelajaran terdiri dari persiapan pembelajaran, pelaksanaan pembelajaran, kualifikasi guru pembimbing dan ketersediaan sarana dan prasarana. Apabilai ke-4 hal tersebut sudah berjalan dengan efektif, maka proses pembelajaran Program UP/J di SMK akan berjalan lancar.

Pengelola UP/J SMK memiliki pedoman yang mengatur berbagai aspek pengelolaan pembelajaran secara tertulis yang mudah dipahami. Pedoman pengelolaan pembelajaran meliputi: (a) KTSP, (b) kalender pendidikan/akademik, (c) struktur organisasi, (d) pembagian tugas di antara guru, (e) pembagian tugas di antara tenaga kependidikan, (f) peraturan akademik, (g) tata tertib UP/J SMK, (h) kode etik SMK, dan (i) biaya operasional SMK. Kurikulum dijadikan acuan utama dalam pembelajaran UP/J SMK, serta melaksanakan penilaian sesuai dengan SKL selama kegiatan praktik di Unit Produksi. Tersedianya media pembelajaran berupa modul, literatur, diktat serta mempunyai perlengkapan praktik untuk kegiatan di UP/J juga sangat penting dalam keberhasilan suatu program unit produksi/jasa di SMK.

\section{Pencapain tujuan Program Unit Produksi/Jasa}

Pencapain tujuan Program UP/J yang dimaksud disini yaitu kompetensi siswa setelah mengikuti kegiatan praktik. Hasil penelitian 
menunjukkan bahwa pencapain tujuan Program UP/J di SMKN Kelompok bisnis dan manajemen di Banjarmasin masih termasuk efektif yaitu 32 responden $(35,6 \%)$. Hal ini menunjukkan bahwa dengan adanya kegiatan praktik Program UP/J di SMKN Kelompok bisnis dan manajemen di Banjarmasin, kompetensi siswa khususnya dalam bidang berwirausaha menjadi lebih baik lagi.

Pengalaman merupakan salah satu faktor penentu untuk kesiapan berwirausaha ataupun bekerja. Dalam rangka menciptakan kesiapan berwirausaha dapat direncanakan melalui pengalaman yang diberikan kepada orang tersebut. Pengalaman merupakan pengetahuan atau keterampilan yang diketahui dan dikuasai seseorang sebagai akibat atau pekerjaan yang telah dilakukan sebelumnya selama jangka waktu tertentu, Seseorang dikatakan berpengalaman apabila telah memiliki tingkat penguasaan pengetahuan dan keterampilan yang relevan dan memadai sesuai dengan bidang keahliannya.

Pengalaman praktik mengikuti kegiatan Program UP/J sangat membantu siswa SMK dalam meningkatkan kompetensinya baik secara kognitif, afektif maupun psikomotor.

\section{Tindak Lanjut Program Unit Produksi/Jasa}

Tindak lanjut program UP/J SMK diantaranya melakukan pencatatan administrasi pendampingan terhadap siswa, mencatat segala permasalahan alumni yang praktik di UP/J, tempat kerja dan atau usahanya merencanakan pendampingan pekerjaan siswa berdasarkan proses pembelajaran pada program UP/J yang telah diikutinya, motivasi dan monitoring serta evaluasi keberhasilan siswa.
Hasil penelitian menunjukkan bahwa tindak lanjut pendampingan Program UP/J di SMKN Kelompok bisnis dan manajemen di Banjarmasin termasuk kategori efektif efektif yaitu 35 responden $(38,9 \%)$.

Faktor pendukung/penghambat pelaksanaan unit produksi sebagai sarana pembelajaran

\section{Faktor Pendukung}

. Faktor-faktor pendukung pelaksanaan UP/J sebagai sarana dapat dijelaskan sebagai berikut.

1. Sumber daya manusia guru yang dimiliki di SMK Kelompok bisnis dan manajemen pada umumnya sudah cukup baik.

2. Fasilitas (sarana dan prasarana), peralatan yang tersedia seperti komputer,kalkulator dan cash register, barcode dan labeling sangat menunjang pelaksanaaan praktik di UP/J walaupun belum seperti layaknya di dunia usaha. Hal ini karena UP/J belum memiliki ruang pembelajaran praktik yang cukup dan alat pengendalian barang dagangan seperti CCTV . Lokasi yang strategis bisnis Center SMKN 1 berada dipinggir jalan komplek mulawarman yang disana terdapat 2 SMU dan 2 SLTP dan juga masyarakat yang tinggal di lingkungan sekolah. Dana hibah dari pusat/daerah.

3. Dana berbentuk hibah yang diberikan pemerintah pusat dan daerah merupakan salah satu faktor pendukung pelaksanaan teaching factory. Dana yang bersifat hibah membuat sekolah lebih leluasa dalam melakukan pengembangan usaha karena dalam perputaran modal tidak dibebani kewajiban untuk mengembalikan dana tersebut. 
4. Dukungan warga sekolah Setiap sekolah memiliki pangsa pasar yang jelas yaitu warga sekolah itu sendiri. Seluruh warga sekolah hendaknya menyadari dan mendukung sepenuhnya akan keberadaan UP/J. Sehingga diharapkan dapat berpartisifasi secara langsung maupun tidak langsung dalam kegiatan di UP/J.

5. Stakeholders (dunia usaha dan dunia industri), dalam masalah persediaan barang dagangan pihak sekolah menjalin kerjasama dengan distributor, berapapun jumlah yang dipesan akan segera dikirim. Tetapi yang menjadi kendala adalah masalah harga yang agak mahal jika dibandingkan dengan swalayan atau hyper mart, sehingga siswa merasa kesulitan dalam memasarkan barang.

\section{Faktor Penghambat}

Persepsi orang tua, sebagian besar orang tua yang tidak mendukung jika anaknya disuruh memasarkan produk.

Tingkat kesibukan yang dimiliki oleh guru dan siswa juga salah satu faktor penghambat. Guru yang dituntut mengajar minimal 24 jam perminggu disertai dengan tuntutan pekerjaan seperti persiapan membuat bahan ajar, koreksi dan penilaian membuat tugas guru sudah cukup padat.

Kurang koordinasi antara pengurus/ karyawan dengan guru kewirausahaan/ pembimbing menjadi salah satu faktor penghambat dalam pelakasanaan teaching factory. Pada umumnya guru yang diberi tugas membimbing siswa sebagian besar tidak terlibat secara langsung dalam kegiatan di UP/J, sehingga guru pembimbing merasa kurang leluasa dalam mengarahkan siswa. Dan siswa sendiri merasa bahwa mereka praktik di UP/J hanya bertanggungjawab dan berkoordinasi dengan pengurus/karyawan.

Komunikasi sesama guru disekolah juga masih menjadi faktor penghambat. Belum semua guru satu persepsi dan memahami program pembelajaran di UP/J. Hal ini kadang menyebabkan guru yang mengajar di kelas keberatan kalau siswanya mengikuti kegiatan di $\mathrm{UP} / \mathrm{J}$.

Pihak distributor tidak bisa memberikan harga yang kompetitif, dengan alasan jumlah pembelian tidak mencapai ketentuan yang ditetapkan. Jika hal ini terjadi otomatis harga barang yang dijual di Bisnis Center lebih mahal dan dampaknya siswa merasa sulit untuk memasarkan barang ke konsumen.

Motivasi siswa dalam pelaksanaan pembelajaran di UP/J masih kurang, sebagian besar mereka belum menyadari bahwa UP/J merupakan wahana pembelajaran praktik. Kegiatan usaha yang dilaksanakan di UP/J seharusnya betul-betul di manfaatkan semaksimal mungkin.

\section{KESIMPULAN}

Berdasarkan hasil penelitian dan pembahasan, maka dapat diambil kesimpulan sebagai berikut:

1. Pengelolaan administrasi pada Program UUP/J di SMKN Kelompok isnis dan manajemen di Banjarmasin sudah efektif $(34,4 \%)$

2. Pelaksanaan pembelajaran pada Program UP.J di SMKN Kelompok bisnis dan manajemen di Banjarmasin sudah termasuk efektif $(36,6 \%)$ 
3. Pencapain tujuan pada Program UP/J di SMKN Kelompok bisnis dan manajemen di Banjarmasin berjalan efektif $(35,6 \%)$.

4. Tindak lanjut pendampingan Program UP/J di SMKN Kelompok bisnis dan manajemen di Banjarmasin sudah termasuk efektif $(38,9 \%)$.

5. a. Faktor pendukung pelaksanaan UP/J Sumber daya manusia, fasilitas yang memadai, dana hibah dari pusat/daerah, partisipasi langsung dari warga sekolah, dan adanya kerjasama yang baik antara sekolah terhadap pihak distributor.

b. Faktor pengahambat/kendala dalam pelaksanaan UP/J yaitu:

Persepsi orang tua yang tidak mendukung anaknya dalam pemasaran produk, keterbatasan waktu yang dimiliki oleh guru dan siswa, kurangnya koordinasi antara guru dengan karyawan, kurangnya komunikasi sesama guru, harga dari produsen yang cukup tinggi, dan kurangnya motivasi siswa.

\section{SARAN}

1. Disarankan kepada pelaksana UP/J untuk memperdalam pemahaman tentang prinsip kegiatan UP/J sebagai sarana belajar dan bekerja (learning by doing), sehingga seluruh siswa hendaknya mendapat kesempatan dan lebih dominan dalam kegiatan praktik di UP/J.

2. Disarankan kepada kepala sekolah lebih menekankan perannya pada UP/J dengan perencanaan tenaga kerja agar UP/J sekolah mempekerjakan manajer profesional bukan guru dengan gaji dari penghasilan UP/J sekolah itu sendiri. Hal ini bermakna manajer yang profesional akan meningkatkan produktivitas dan pengetahuan siswa serta membantu kerja guru dalam mewujudkan pelaksanaan UPJ sebagai sarana pembelajaran.

3. Disarankan kepada guru baik yang terlibat langsung di UP/J atau guru yang tidak masuk dalam jajaran kepengurusan UP/J untuk lebih meningkatkan perannya sebagai motivator dan pembimbing siswa dengan memperjelas tujuan penyelenggaraan UP/J, memperjelas tugas yang harus dikerjakan siswa. Mempersiapkan pengetahuan, sikap dan keterampilan siswa dalam bidang masing-masing sesuai dengan kurikulum yang diberlakukan di SMK melalui pembelajaran dikelas.

\section{DAFTAR PUSTAKA}

Fidler.B (2002) Strategic management school development.London:Paul Chapman Publishing.

Finch, R., Curtis. \& Crunkilton, R., (1999) Curriculum development in vocational and technical education: Planning, content, and implimentation. Needham Heights, MA: Allyn \& Bacon.

Finch Curtis and Clinkton R John (1993), Curriculum Development in Vocational and Technical Education, Planning, content, implimentation Boston : Allyn and Bacon

Gibson, James L., Ivancevich, John M., Donelly, James H. Jr., Konopaske, obert. (2006). Organizations: Behavior, structure, processes. Twelfth

Hani Handoko (2003). Manajemen Yogyakarta: BPFE.
Hadari Nawawi (2006). Evaluasi dan manajemen kinerja dilingkungan perusahaan dan industri. Yogyakarta: Gadjah Mada University Press.


Kunandar (2007) Guru profesional implementasi KTSP dan sukses dalam sertifikasi guru. Jakarta : RajaGrafindo Persada

McDavid.J \& Hawthorn. L (2006). Program Evaluation \& Performance Measurement:An Introduction to Practice, London:by Sage Publications,Inc.

PMPTK DEPDIKNAS (2007). Pedoman manajemen unit produksi/jasa sebagai sumber belajar siswa dan penggalian dana pendidikan persekolahan.

Rappe, Christoph. \& Zwick, Thomas. (2007). Developing leadership competence of production unit managers. The Journal of Management Development. Bradford: 2007. Vol. 26, Iss. 4; pg. 312

Uzer Usman,M. (2007). Menjadi guru profesional. Bandung: Rosdakarya

Serian Wijatno, (2009). Pengelolaan perguruan tinggi secara efisien, efektif dan ekonomis. Jakarta : Salemba Empat

Wina Sanjaya. (2005). Pembelajaran dalam implementasi kurikulum berbasis kompetensi. Jakarta: Kencana Prenada Media Group. 